Борисов Т. Удмурт кыллюкам = Толковый удмуртско-русский словарь. Ижевск, 1991.

КЭСКЯ - Льтткин В. И., Гуляев Е. С. Краткий этимологический словарь коми языка. М., 1970.

Тараканов И. В. Удмуртско-тюркские языковые взаимосвязи. Ижевск, 1993.

DOI 10.31168/7996-2700-3.43

\author{
Габор Дьёни \\ Университет им. Лоранда Этвеша \\ Будапешт, Венгрия \\ dominus2006@yandex.ru
}

\title{
Имя, народ, история
}

«Башкирская проблематика» имеет давние традиции в венгерской историографии. Суть вопроса заключается в том, можно ли найти венгерские следы на территории Башкирии, т. е. свидетельства о некогда живших там венграх.

Предполагаемые «венгерские следы» в Башкирии были исследованы с разных сторон. Наряду с историей (сообщения европейских монахов и венгерских хронистов с XIII в. о Башкирии как древней родине мадьяр), археологией (отождествление нескольких археологических культур на территории современного Башкортостана с протомадьярами), фольклором (известие об уральских можарах в башкирском фольклоре) видное место в «башкирском вопросе» занимает языкознание. Это связано, во-первых, с исследованием возможных языковых контактов между мадьярами и башкирами, а во-вторых — с выявлением возможной угорской (прото)мадьярской топонимии на территории современного Башкортостана. Если на первый вопрос ответ отрицателен (следы прямых контактов между венгерскими и башкирскими языками найти не удалось), то решение «топонимического» вопроса не так уж однозначно.

Дискуссия об угорском (даже мадьярском) топонимическом пласте и в конечном счете о венгерском присутствии в Приуралье также имеет давнее прошлое. Уже в XVIII в. Г. Ф. Миллер и другие исследователи (C) Дьёни Г., 2019 
обратили внимание на угорскую топонимию Приуралья. В «классической» башкирской топонимической традиции (Д. Г. Киекбаев, А. А. Камалов, Ф. Г. Хисамитдинова, репрезентативный «Словарь топонимов Республики Башкортостан») и в уральской ономастической школе А. К. Матвеева допускали присутствие венгерских топонимических следов в Приуралье.

Однако венгерская тюркология пошла по другой линии. C конца XIX — начала XX в. благодаря работам Д. Месароша стало преобладать мнение о том, что никаких башкирско-венгерских контактов не было. Этот отрицательный, критический подход до настоящего времени определяет характер венгерских исследований (А. Рон-Таш, И. Вашари) - несмотря на то, что были ученые (Д. Немет, Л. Рашони), которые все же допускали наличие на территории Башкирии каких-то венгерских следов, особенно в связи с венгерскими племенными названиями (например, дьярмат - юрматы). Их тезисы остались спорными и не разделяются всеми исследователями.

Причины этого отрицательного подхода, на мой взгляд, кроются в особенностях венгерской историографии - в том, что, во-первых, всякие необоснованные «тюркизмы» подозрительны, несут подтекст национализма (ввиду того, что у венгерских националистов популярен тезис, будто венгры - это тюрки); во-вторых, разные фантастические этимологии уже неоднократно вызывали раздражение научного сообщества. Я не лингвист, свои собственные этимологии предлагать не могу, а лишь отмечаю, что в работах «отрицателей» мы не видим ссылок на труды вышеупомянутых исследователей (А. К. Матвеева, А. А. Камалова и др.), а те этимологии, которые предлагаются, не всегда безупречны семантически - например, возведение оронима Magaš к иранскому слову со значением 'комар' (вместо (прото)мадьярского 'высокий').

Независимо от главного течения венгерской историографии, этот отрицательный подход наблюдается также в некоторых работах башкирских историографов.

На мой взгляд, в башкиро-мадьярской проблематике в методологическом смысле до сих пор определяющим является мнение академика Б. А. Серебренникова, согласно которому венгры массово не участвовали в этногенезе башкир, в башкирском языке нет заимствованных из венгерского слов, башкиры не могли прийти в Приуралье раньше булгар. 